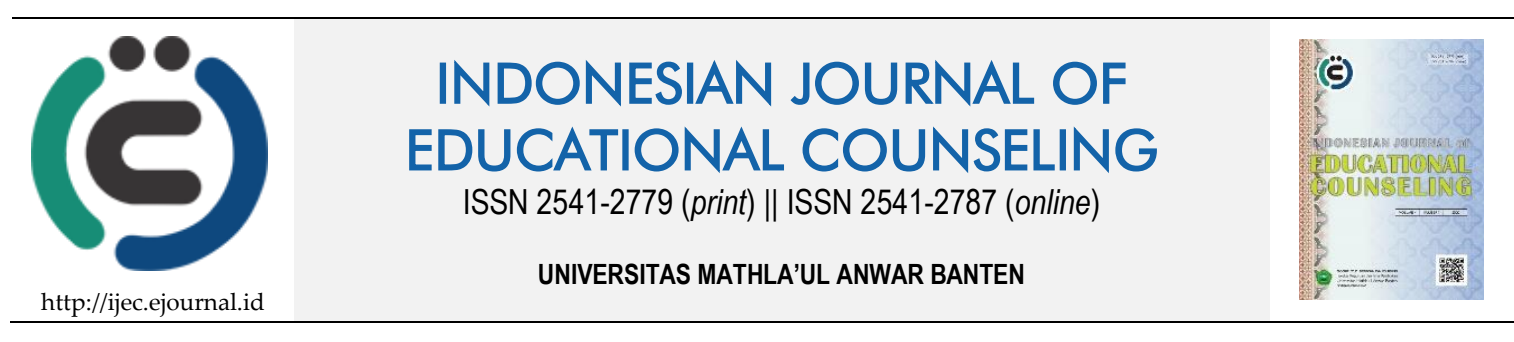

Research Based Article

\title{
Pengembangan Inisiatif, Kemandirian, dan Tanggung Jawab untuk Meningkatkan Kualitas Pembelajaran Peserta Didik
}

\author{
Suherman ${ }^{1}$, Amin Budiamin² \\ 1, 2 Universitas Pendidikan Indonesia, Indonesia
}

\begin{tabular}{lllll}
\hline Article History & ABSTRACT & & & \\
\hline Received: 20.12 .2019 & DEVELOPMENT & OF & INITIATIVES, & INDEPENDENCE, AND
\end{tabular}

Received in revised form: 08.01.2020

Accepted: 19.12.2019

Available online: 28.01 .2020 \begin{abstract}
RESPONSIBILITIES FOR IMPROVING THE OUALITY OF STUDENT LEARNING. The learning process will take place effectively and productively if students have psychological competence and strength in the form of initiative, independence, and responsibility in learning activities. Students who have the initiative, independence, and low responsibility are suspected to experience obstacles and difficulties in the learning process, and will be trapped in immaturity and stagnation in development. This research aims to develop guidelines for the development of initiatives, independence, and responsibility, so that students can undergo the learning process effectively and independently. If students have the initiative, independence, and responsibility, the learning process is expected to produce quality outputs that can develop students to have abilities according to their potential, can face future challenges, and have quality job and career orientation, so they are able to compete in a global society. With a quasi-experimental method and collaborative action research approach, this study involved 260 respondents and two guidance and counseling teachers in two state junior high schools in West Bandung Regency. The research produced guidelines that were tested that could effectively develop the initiative, independence, and responsibility of junior high school students.

KEYWORDS: Effective Learning Process, Independence, Initiative, Learning Quality, Responsibility.
\end{abstract} Attribution 4.0 International License, which permits unrestricted use, distribution, and reproduction in any medium, provided the original work is properly cited. (c) 2020 Suherman, Amin Budiamin.

\section{PENDAHULUAN}

Dalam kegiatan pembelajaran di sekolah, siswa dituntut untuk memiliki kepribadian yang efektif, kreatif, produktif, dan mampu berinteraksi, menyesuaikan diri, mengelola, dan mendayagunakan lingkungan sebagai fasilitas perkembangan yang kondusif. Siswa SMP seyogianya memiliki kemandirian dan tanggung jawab yang merupakan kekuatan internal dalam mengembangkan inisiatif dan kemampuan memilih tindakan yang efektif dalam mencapai tujuan.

${ }^{1}$ Corresponding author's address: Program Studi Bimbingan dan Konseling Sekolah Pasca Sarjana Universitas Pendidikan Indonesia. Jl. Dr. Setiabudi No.229, Isola, Kec. Sukasari, Kota Bandung, Jawa Barat 40154, Indonesia. Email: suhermanbk@upi.edu 
Kemandirian dan tanggung jawab dalam menentukan pilihan dirasakan semakin penting untuk menghadapi kondisi kehidupan yang senantiasa berubah dan bertambah kompleks. Dalam berbagai dimensi, kompleksitas tersebut menjadi bagian yang tidak terpisahkan dari setiap proses kehidupan. Selain itu, perubahan yang semakin cepat dan meluas, menuntut individu untuk melakukan penyesuaian diri, dan pengelolaan diri yang akan berlangsung dalam sepanjang rentang perjalanan hidupnya.

Siswa yang memiliki inisiatif, kemandirian, dan tanggungjawab akan memiliki kepekaan dalam melihat peluang, kekuatan untuk menghindari hambatan, kejelian dalam menghadapi tantangan, dan ketepatan serta konsistensi dalam melakukan tindakan. Proses pembelajaran di sekolah hendaknya berupaya untuk menciptakan kondisi agar siswa mampu membimbing, mengatur, dan mengarahkan dirinya dalam mencapai tujuan.

Berbagai tantangan dalam kehidupan siswa, menuntut sekolah untuk menyediakan program pengembangan inisiatif, kemandirian, dan tanggungjawab. Program tersebut memfasilitasi siswa agar memiliki kemampuan memilih berbagai alternatif dan mengambil keputusan, serta merespon secara positif terhadap tantangan-tantangan dan peluang-peluang yang terdapat pada diri dan lingkungannya. Dengan dimilikinya inisiatif, kemandirian, dan tanggungjawab siswa diharapkan dapat menjalani kehidupannya secara terfokus, bertujuan, fungsional, dan dapat mengoptimalisasi perkembangannya secara efisien.

Atas dasar fenomena-fenomena di atas, dirasakan penting untuk mengembangkan inisiatif, kemandirian, dan tanggungjawab. Program tersebut perlu diselenggarakan sebagai upaya untuk meningkatkan proses belajar efektif para siswa, sehingga mereka mampu menghadapi berbagai tantangan, serta dapat memanfaatkan setiap peluang dan fasilitas yang tersedia dalam mengoptimalisasi perkembangannya. Dengan demikian, siswa diharapkan dapat menjalani proses pembelajaran secara efektif, kreatif, dan produktif.

Pengembangan inisiatif, kemandirian, dan tanggungjawab siswa dalam layanan bimbingan dan konseling di sekolah memerlukan strategi yang teruji secara rasional dan empirik dalam praktik di lapangan. Demikian pula, harapan siswa terhadap penerimaan dari guru bimbingan dan konseling merupakan faktor yang menentukan keberhasilan pemberian bantuan. Perlakuan guru bimbingan dan konseling yang tidak diterima oleh siswa merupakan penyebab utama kegagalan layanan bimbingan dan konseling di sekolah.

Berdasarkan paparan di atas, penelitian ini difokuskan pada upaya menemukan strategi bimbingan dan konseling yang efektif guna mengembangkan inisiatif, kemandirian, dan tanggungjawab siswa. Demikian pula, dalam mengimplementasikan strategi tersebut diperlukan guru bimbingan dan konseling yang memiliki kompetensi memadai dalam interaksi pemberian bantuan dengan siswa untuk mengembangkan inisiatif, kemandirian, dan tanggungjawab.

\section{METODE}

Penelitian ini bertujuan untuk mengembangkan panduan untuk menumbuhkan inisiatif, kemandirian, dan tanggungjawab siswa SMP. Sesuai dengan fokus, 
permasalahan, dan tujuan penelitian, pendekatan penelitian menggunakan rancangan penelitian pengembangan (research and development). Penelitian pengembangan (RD) diarahkan untuk memperoleh strategi layanan bimbingan dan konseling yang efektif dalam menumbuhkan inisiatif, kemandirian, dan tanggungjawab siswa SMP.

Pendekatan yang digunakan dalam penelitian ini adalah pendekatan analisis deskriptif, mengaplikasikan metode collaborative action research dan quasy eksperiment dengan melibatkan guru-guru BK dan siswa SMP Negeri di Kabupaten Bandung Barat sebagai sampel. Dengan pendekatan ini diproyeksikan dapat ditemukan prosedur yang efektif dalam menerapkan strategi pengembangan inisiatif, kemandirian, dan tanggungjawab siswa SMP.

Langkah-langkah penelitian meliputi studi pendahuluan, need assessment, dan perumusan panduan pengembangan kecakapan pengarahan diri untuk siswa SMP. Puncak kegiatan penelitian adalah berlangsungnya uji coba Panduan Pengembangan Kecakapan Inisiatif, Kemandirian, dan Tanggungjawab bagi Siswa SMP.

Anggota populasi penelitian ini adalah seluruh siswa kelas 8 dan Guru BK SMP Negeri di Kabupaten Bandung Barat. Sampel ditetapkan secara purposif sesuai karakteristik penelitian, yaitu sejumlah 260 orang siswa dan 2 orang guru BK.

Untuk memperoleh data yang dibutuhkan guna pengujian efektivitas Panduan Pengembangan Kecakapan Inisiatif, Kemandirian, dan Tanggungjawab Siswa SMP dikembangkan dua buah instrumen penelitian, yaitu: (1) angket pengungkap inisiatif, kemandirian, dan tanggungjawab, (2) angket pengungkap kompetensi guru bimbingan dan konseling dalam pengembangan inisiatif, kemandirian, dan tanggungjawab siswa.

\section{HASIL DAN PEMBAHASAN}

\section{Hasil Penelitian}

\section{Gambaran Kecakapan Inisiatif, Kemandirian, dan Tanggungjawab Siswa}

Berdasarkan identifikasi pemilikan inisiatif, kemandirian, dan tanggungjawab terhadap 260 orang siswa kelas 8 pada 2 SMP Negeri di Kabupaten Bandung Barat diperoleh gambaran tentang adanya sejumlah masalah siswa seperti berikut: (a) mengalami kesulitan dalam mengatur waktu untuk menyelesaikan tugas sekolah $(89,6 \%)$; (b) mengharapkan bantuan untuk menemukan jati diri (85,5\%); (c) suka melakukan kegiatan di luar tugas-tugas sekolah $(71,7 \%)$; (d) mengalami kesulitan dalam memanfaatkan waktu secara efektif $(84,6 \%)$; (e) kurang memiliki keberanian untuk mengemukakan pendapat (78,5\%); (f) suka menunda-nunda tugas-tugas sekolah $(72,4 \%)$; (g) merasa kesulitan dalam memilih kegiatan yang menunjang cita-cita $(62,3 \%)$; (h) apabila mengalami kegagalan suka menyalahkan pihak di luar dirinya $(62,8 \%)$; (i) mengalami kesulitan dalam memilih kegiatan (58,9\%); (j) memiliki kesulitan dalam menggunakan waktu luang (68,4\%); (k) ketergantungan kepada guru $(66,3 \%)$; (1) melakukan kegiatan yang tidak bermanfaat $(52,4 \%) ;(\mathrm{m})$ mengabaikan tugas-tugas yang diberikan guru (46,5\%); (n) melakukan kegiatan tanpa rencana (44,1\%). Data tersebut, memberikan gambaran tentang rendahnya inisiatif, kemandirian, dan tanggungjawab siswa, yang berimplikasi pada perlunya intervensi bimbingan dan konseling untuk mengembangkannya. 
Perumusan dan Uji Keterbacaan Panduan Pengembangan Inisiatif, Kemandirian, dan Tanggungjawab Siswa SMP

Dengan rendahnya pemilikan inisiatif, kemandirian, dan tanggungjawab siswa SMP, maka dirumuskan Panduan Pengembangan Kecakapan Inisiatif, Kemandirian, dan Tanggungjawab Siswa Sekolah Menengah Pertama. Agar panduan tersebut dapat dipahami dengan baik oleh pengguna panduan (antara lain: pimpinan sekolah, wali kelas, guru BK, dan siswa), maka dilakukan uji keterbacaan. Pengujian keterbacaan panduan merupakan proses untuk menginventarisasi masukan bagi perbaikan Panduan Pengembangan Kecakapan Inisiatif, Kemandirian, dan Tanggungjawab Siswa Sekolah Menengah Pertama.

Pelaksanaan pengujian keterbacaan melibatkan 2 orang guru BK berkualifikasi sarjana bimbingan dan konseling, tiga orang mahasiswa program Pendidikan Profesi Guru BK, dan lima orang siswa SMP kelas 8.

Pengujian keterbacaan redaksi dan isi panduan dimaksudkan agar panduan tersebut dapat dengan mudah dipahami guru BK, Wali Kelas, dan staf sekolah lainnya. Masukan bagi perbaikan redaksi dan isi langsung diterakan pada naskah panduan. Penyesuaian konsep dengan praksis bimbingan dan konseling di sekolah, prosedur dan teknik pelaksanaan bimbingan, serta implementasi permainan dan ice breaking, didiskusikan antara judger dengan peneliti sebagai pengembang panduan, perubahan dan perbaikannya langsung diterakan pada naskah panduan.

\section{Uji Coba Panduan Pengembangan Inisiatif, Kemandirian, dan Tanggungjawab}

Uji coba Panduan Pengembangan Kecakapan Inisiatif, Kemandirian, dan Tanggungjawab Siswa Sekolah Menengah Pertama dilaksanakan kepada siswa kelas 8 pada 2 SMP Negeri di Kabupaten Bandung Barat diikuti oleh 260 orang siswa. Pelaksanaan uji coba dilakukan dalam seting bimbingan kelompok.

Uji coba Panduan Pengembangan Kecakapan Inisiatif, Kemandirian, dan Tanggungjawab Siswa Sekolah Menengah Pertama diawali dengan persiapan melalui pelatihan guru BK yang memiliki kompetensi dan pengalaman dalam pelaksanaan bimbingan dan konseling di SMP, serta memberikan dukungan mental dan kepercayaan untuk melaksanakan pengembangan inisiatif, kemandirian, dan tanggungjawab di sekolah masing-masing.

Pengembangan inisiatif, kemandirian, dan tanggungjawab pada masing-masing sekolah dilaksanakan oleh seorang guru BK dibantu oleh seorang fasilitator. Peneliti melakukan manajemen dan pengendalian dalam pengorganisasian pelaksanaan uji coba, waktu, dan sarana yang diperlukan. Pemantauan pelaksanaan uji coba dilakukan peneliti pada masing-masing sekolah.

Dalam pelaksanaannya, dengan bimbingan kelompok, guru BK mencatat aspekaspek penting dari proses bimbingan, antara lain: pemahaman siswa tentang pokokpokok materi inisiatif, kemandirian, dan tanggungjawab, kesesuaian dengan kebutuhan siswa, komunikasi dalam proses bimbingan antara guru BK dengan siswa, keterlibatan siswa dalam proses bimbingan, dan aspek-aspek lain yang relevan. Diskusi dan refleksi dilakukan setiap akhir proses bimbingan untuk mengidentifikasi masukan bagi perbaikan panduan.

Tahap-tahap proses uji coba dalam implementasi Panduan Pengembangan Kecakapan Inisiatif, Kemandirian, dan Tanggungjawab Siswa Sekolah Menengah Pertama adalah sebagai berikut. 
Tahap permulaan. Pada tahap ini guru BK menyiapkan pembentukan kelompok dan memberi penjelasan tentang tujuan kegiatan. Tahap transisi. Pada tahap ini, guru BK membangun minat dan komitmen kerja sama antara siswa dengan guru BK. Tahap inti kegiatan, mengeksplorasi materi kecakapan inisiatif, kemandirian, dan tanggungjawab dengan berbagai srategi. Tahap akhir. Pada tahap ini, guru BK melaksanakan evaluasi, refleksi, tindak lanjut, dan penutupan proses bimbingan.

\section{Kompetensi Guru Bimbingan dan Konseling dalam Mengembangkan Inisiatif, Kemandirian, dan Tanggungjawab}

Persepsi siswa tentang perlakuan guru bimbingan dan konseling yang diharapkan dalam pengembangan inisiatif, kemandirian, dan tanggungjawab siswa dapat dilihat dalam tabel berikut.

Tabel 1. Harapan Siswa Terhadap Bimbingan Guru BK dalam Pengembangan Kecakapan Pengarahan diriSiswa (n: 260)

\begin{tabular}{ll}
\hline Aspek dan Indikator & $\%$ \\
\hline Mengelola Materi Bimbingan & 92,78 \\
\hline Merencanakan materi bimbingan & 94,00 \\
\hline Menguasai materi bimbingan & 94,71 \\
\hline Menarik dalam menyampaikan materi bimbingan & 96,87 \\
\hline Menumbuhkan Kepercayaan Siswa & 95,91 \\
\hline 1. Mengembangkan kerjasama dengan siswa & 92,78 \\
\hline 2. Bersikap sabar terhadap siswa & \\
\hline 3. Peka terhadap pikiran, perasaan, dan kesulitan siswa & 94,95 \\
\hline Berkomunikasi Empatik dengan Siswa & 94,00 \\
\hline 1. Menunjukkan perhatian kepada seluruh siswa & 94,00 \\
\hline 2. Bersahabat dan ramah & 94,00 \\
\hline Memberikan Dorongan & 95,91 \\
\hline 1. Menerima dan mempercayai usaha siswa & 96,87 \\
\hline 2. Menyemangati siswa untuk mencoba melakukan & \\
\hline 3. Memberi penghargaan atas hasil yang dicapai siswa & 95,91 \\
\hline Mengembangkan Sikap Positif dan Terbuka & 92,78 \\
\hline 1. Bersikap terbuka terhadap pendapat siswa & 94,95 \\
\hline 2. Ramah dan penuh pengertian & \\
\hline 3. Bergairah dan menerima siswa apa adanya &
\end{tabular}

\section{Pembahasan}

Inisiatif, kemandirian, dan tanggungjawab merupakan kekuatan psikologis untuk meningkatkan kualitas proses belajar dalam upaya mencapai tujuan dan cita-cita yang diharapkan siswa. Inisiatif, kemandirian, dan tanggungjawab perlu dikembangkan untuk membantu siswa dalam mengoptimalkan pemanfaatan sumber-sumber dan fasilitas yang terdapat dalam diri dan lingkungan agar berkontribusi secara maksimal dalam menumbuhkan perilaku belajar efektif. Inisiatif, kemandirian, dan tanggungjawab memberikan kesempatan kepada siswa untuk memanfaatkan berbagai sumber belajar dan menerapkan gaya belajar yang sesuai dengan potensi yang dimilikinya. 
Pentingnya pemilikan inisiatif, kemandirian, dan tanggungjawab siswa perlu mendapat perhatian dalam layanan bimbingan dan konseling sekolah. Hasil studi pendahuluan menggambarkan lima masalah tertinggi yang dihadapi siswa terkait dengan pemilikan inisiatif, kemandirian, dan tanggungjawab, adalah sebagai berikut: (1) kesulitan mengatur waktu dalam menyelesaikan tugas sekolah, (2) kesulitan untuk mendapatkan pihak yang dapat membantu menemukan jati diri, (3) kesulitan dalam memilih kegiatan yang menunjang tugas-tugas sekolah, (4) kurang memiliki keberanian untuk mengemukakan pendapat, dan (5) kesulitan dalam memilih kegiatan yang menunjang cita-cita.

Data di atas menggambarkan tentang pentingnya pengembangan inisiatif, kemandirian, dan tanggungjawab siswa di sekolah dirancang dan ditata secara sistematis dalam layanan bimbingan dan konseling yang terprogram. Dalam penerapannya, perlu melibatkan guru BK, wali kelas, guru mata pelajaran, manajemen sekolah, dan staf sekolah lainnya dengan berorientasi pada kebutuhan untuk memfasilitasi dan mengoptimalkan perkembangan siswa.

Diyakini bahwa setiap individu memiliki kebutuhan untuk mengembangkan pengetahuan (need to know), dan memiliki inisiatif, kemandirian, dan tanggungjawab. Secara alamiah siswa memiliki rasa ingin tahu (curiosity) dan memiliki keinginan untuk mengembangkan kemampuan-kemampuan potensial yang dimilikinya. Pemilikan inisiatif, kemandirian, dan tanggungjawab merupakan fasilitas untuk memenuhi kebutuhan dalam mengembangkan keterampilan belajar serta memahami perspektif baru yang muncul dalam kehidupan dengan kesempatan memilih dan mengembangkan diri yang semakin terbuka. Program BK di sekolah dapat memfasilitasi pengembangan inisiatif, kemandirian, dan tanggungjawab siswa antara lain dengan memberikan pemahaman tentang pentingnya pengembangan proses belajar efektif.

Hasil uji coba dalam penelitian ini memberikan gambaran bahwa Panduan Pengembangan Inisiatif, Kemandirian, dan Tanggungjawab bagi Siswa SMP secara efektif dapat mengembangkan inisiatif, kemandirian, dan tanggungjawab siswa. Kecakapan inisiatif, meliputi kemampuan membuat rencana, mengendalikan kegiatan, dan menjalin kerjasama. Kemandirian, meliputi mengembangkan tujuan, memiliki misi pribadi, dan menilai diri secara positif. Kecakapan bertanggung jawab meliputi mengambil keputusan, keberanian mengambil resiko, memiliki orientasi nilai, dan memiliki komitmen.

Inisiatif, kemandirian, dan tanggungjawab merupakan kekuatan psikologis yang sangat penting dimiliki siswa guna menata masa depan dan mengembangkan proses belajar efektif. Dengan demikian, siswa akan memiliki kemampuan untuk menginventarisasi kebutuhan belajar, merencanakan kegiatan dalam pencapaian tujuan, dan mengidentifikasi fasilitas dan cara-cara yang harus ditempuh dalam mencapai tujuan yang ingin diraih.

Menurut Brammer (2009) iklim pemberian bantuan yang kondusif dalam helping relationship yang perlu dikembangkan guru BK adalah: (a) pemahaman empatik terhadap pribadi siswa, (b) penerimaan dan penghargaan terhadap pribadi siswa, (c) kehangatan dalam menerima siswa, (d) keaslian dan keterbukaan (genuiness), dan (e) keajegan dalam tindakan atau kongruensi.

Kompetensi guru BK yang perlu dimiliki dalam mengimplementasikan Panduan Pengembangan Kecapakan Inisiatif, Kemandirian, dan Tanggungjawab, adalah sebagai berikut. 
1) Memiliki kemampuan dalam memahami materi bimbingan untuk mengembangkan inisiatif, kemandirian, dan tanggungjawab, meliputi: (a) merencanakan materi bimbingan, (b) menguasai materi bimbingan, dan (c) menyajikan materi bimbingan secara menarik.

2) Menumbuhkan kepercayaan diri siswa. Upaya-upaya guru BK untuk menumbuhkan kepercayaan siswa berupa: (a) pengembangan kerja sama; (b) bersikap sabar; dan (c) peka terhadap pikiran, perasaan, dan kesulitan siswa.

3) Berkomunikasi empatik dengan siswa. Layanan bimbingan pada dasarnya merupakan komunikasi interpersonal antara guru BK dengan siswa (konseli). Keberhasilan layanan bimbingan dipengaruhi oleh keefektifan komunikasi antara guru BK dengan siswa. Aspek ini mencakup: (a) menunjukkan perhatian kepada seluruh siswa; (b) bersahabat dan ramah; dan (c) memahami ekspresi lisan, tulisan, dan tindakan siswa.

4) Memberi dorongan. Aspek ini meliputi: (a) menerima dan mempercayai usaha siswa; (b) menyemangati siswa untuk mencoba melakukan; dan (c) memberi penghargaan atas hasil yang dicapai siswa.

5) Mengembangkan sikap positif dan terbuka. Aspek ini mencakup: (a) bersikap terbuka terhadap pendapat siswa; (b) ramah dan penuh pengertian; (c) bergairah dan menerima siswa apa adanya.

Layanan bimbingan dan konseling sekolah hendaknya mampu menciptakan lingkungan perkembangan yang sehat yang dapat membantu siswa mengembangkan perilaku efektif melalui interaksi yang dirancang untuk mencapai perkembangan optimal.

Penciptaan lingkungan belajar sebagai fasilitas perkembangan dengan menyediakan sistem peluang, sistem pendukung, dan sistem penghargaan dari seluruh masyarakat sekolah sangatlah diperlukan. Keterlibatan, kerja sama, dan tanggung jawab seluruh staf sekolah, yang dalam pelaksanaannya dikoordinasikan oleh kepala sekolah sangat penting bagi terselenggaranya bimbingan dan konseling untuk mewujudkan kapasitas potensial yang dimiliki siswa. Penggunaan bimbingan kelompok dan peercounseling (konseling sebaya) dalam upaya pengembangan inisiatif, kemandirian, dan tanggungjawab merupakan strategi bimbingan yang dapat digunakan secara efektif dengan menata perangkat-perangkatnya dan mengefektifkan setiap fase dalam bimbingan kelompok.

Guru BK perlu merancang, menata, dan menciptakan kondisi bagi terciptanya lingkungan belajar sebagai lingkungan perkembangan yang kondusif.

Lingkungan belajar merupakan salah satu faktor determinan dalam pengembangan inisiatif, kemandirian, dan tanggungjawab siswa. Siswa difasilitasi dalam menggunakan berbagai strategi untuk dapat meraih hasil belajar yang diharapkan, dengan cara mengembangkan keterampilan berinteraksi, merespon setiap dukungan orang lain yang terarah kepada upaya pemberian tanggung jawab untuk belajar (Chen, Willits, dan Moore, dalam Klopfenstein, 2003).

Strategi efektif untuk mengembangkan inisiatif, kemandirian, dan tanggungjawab siswa antara lain sebagai berikut.

1) Mengembangkan proses pembelajaran kolaboratif, akomodatif, dan memberikan dukungan kepada siswa untuk belajar menghadapi berbagai permasalahan, mendapatkan pengalaman hidup yang berharga, dan menghadapi tantangan untuk berpikir. 
2) Mengembangkan kerjasama, tukar pengalaman, dan dukungan yang menguntungkan antara guru BK dengan siswa.

3) Memberikan berbagai variasi sumber informasi untuk mengembangkan beragam gaya belajar dan menstimulasi proses pembelajaran.

4) Mengembangkan kegiatan pembelajaran aktif yang relevan, seperti studi kasus, projek penelitian, seminar, pembelajaran berbasis masalah, dan diskusi terbuka untuk mengkonstruksi pengetahuan.

5) Memfasilitasi siswa dalam mengeksplorasi pilihan, pengendalian diri, dan pemberian kesempatan untuk mencoba.

6) Menggunakan kesempatan untuk melakukan refleksi mengenai pengalaman belajar dan isi proses belajar.

7) Mempromosikan pemikiran kritis yang dikemukakan oleh siswa dengan memberikan klarifikasi dan balikan yang bermakna.

\section{SIMPULAN}

Berkaitan dengan pelaksanaan program bimbingan dan konseling di sekolah, hasil analisis program bimbingan dan konseling dan diskusi dengan guru bimbingan dan konseling, menunjukkan bahwa: (a) pelaksanaan kegiatan pengembangan inisiatif, kemandirian, dan tanggungjawab belum secara terencana diakomodasi dalam program bimbingan dan konseling, (b) manajemen layanan bimbingan dan konseling untuk mengembangkan inisiatif, kemandirian, dan tanggungjawab, belum tertata secara sistematis, dan (c) bidang layanan pribadi khususnya layanan pengembangan inisiatif, kemandirian, dan tanggungjawab siswa belum terakomodasi secara sistematis.

Setelah mengkaji konsep bimbingan dan konseling perkembangan, pemilikan inisiatif, kemandirian, dan tanggungjawab siswa, analisis kebutuhan pengembangan inisiatif, kemandirian, dan tanggungjawab siswa, dan hasil analisis program bimbingan dan konseling sekolah, dirumukan Panduan Pengembangan Kecakapan Inisiatif, Kemandirian, dan Tanggungjawab bagi Siswa Sekolah Menengah Pertama. Panduan ini diharapkan memiliki ketepatan dan keefektivan untuk diterapkan sebagai panduan layanan bimbingan dan konseling dalam mengembangkan inisiatif, kemandirian, dan tanggungjawab siswa Sekolah Menengah Pertama.

Prosedur bimbingan dan konseling perkembangan dalam pengembangan inisiatif, kemandirian, dan tanggungjawab siswa, akan efektif dengan mengimplementasikan strategi bimbingan dan konseling kelompok, yang dilaksanakan dalam empat tahap kegiatan, yaitu tahap permulaan, tahap transisi, tahap kegiatan inti, dan tahap akhir.

Kompetensi guru bimbingan dan konseling yang diperlukan dalam pengembangan inisiatif, kemandirian, dan tanggungjawab siswa meliputi: mengelola materi bimbingan, menumbuhkan kepercayaan diri siswa, berkomunikasi empatik dengan siswa, memberikan dorongan, dan mengembangkan sikap positif dan terbuka. 


\section{REFERENSI}

Blocher, D. H. (2016). Developmental counseling, New York: John Willey \& Son.

Bolton, R. (2013). People skills. New York: A Viacom Company.

Borg, W. R., \& Gall, M. D. (1989). Educational research: An introduction. Fifth Edition. New York: Longman.

Brammer, L. M. (1998). The helping relationship: Process and skills. New Jersey: Prestice Hall.

Carkhuff, R. R. (2009). The art of helping. Massachusetts: HRD Press.

Cemes, H., \& Rean, R. (2014). Petunjuk praktis bagi orang tua dan guru membangkitkan harga diri anak. Jakarta:Mitra Utama.

Cobb, N. J. (2010). Adolescence, continuity, change and diversity. California: Mayfield Publishing Company.

Coleman, D. (2008). Emotional intelegence: Kecerdasan emosional. Jakarta: Gramedia.

Covey, S. R. (2003). The 7 habits of highly effective people. New York: Simon and Schuster.

Dave, M. (2005). Critical issue: Working toward student self direction and personal efficacy as educationa goal. Stanford, CA: Stanford University.

Permendikbud No. 111 tahun 2014 tentang Petunjuk Pelaksanaan Bimbingan dan Konseling dalam Jalur Pendidikan Formal. Jakarta: Ditjen Mandikdasmen Kemendikbud.

Edward, A. L. (2018). Attitude scale construction: Theories and practices. New York: McGrawHill.

Felstiner, S. (2016). Development of self direction. Stanford, CA: Stanford University.

Gardner, H. (2013). Frames of mind.the multiple intelegence. New York: Basic Books.

Gazda, G. M. (2014). Group counseling a develpomental approach. Boston: Allyn and Bacon.

Gibson, R., \& Mitchell, M. H. (2007). Introduction to counseling and guidance. Columbus, Ohio: Merill.

Klopfenstein, B. J. (2013). Empowering learners: Strategies for fostering self-directed learning and implication for online learning. Edmunton Alberta: The University of Alberta Departement of Elementary Education. 
Lee, J., \& Gibson, C. C (2016). Developing self-direction in an online course though computer-mediated interaction. The American Journal of Distance Education, 17(3), 173187.

Muro, J. J., \& Kottman, T. (2015) Guidance and counseling in the elementary and midde schools. Agoura, CA: Brown \& Benchmark.

Myrick, R. D. (2013). Developmental guidance and counseing: a practical approach (Second edition). Minneapolis: Educational Media Coorporation.

Pulkkinen, L., \& Rönkä, A. (1994). Personal control over development, identity formation, and future orientation as components of life orientation: A developmental approach. Developmental Psychology, 30(2), 260-271.

Schmidt, J. J. (2014). Counseling in school essential service and comprehensive programs. Boston: Allyn \& Bacon.

Shetzer, B., \& Stone, S. (2010). Fundamental of counseling. Boston: Houghton Mifflin Company.

Steinberg, L. (2010). Adolescent. New York: McMillan Publishing.

Wallace, W. A (2014). Theory of counseling and psychotherapy. Boston: Allyn \& Bacon.

Yusuf LN, S. (2016). Psikologi perkembangan anak dan remaja. Bandung: Rosda Karya. 